\title{
Identifying the Current Trends of Entrepreneurial Education in Pakistani Higher Education Institutions
}

\author{
Shaista Noora*, Filzah Md. Isaa, Leilanie Mohd Nor ${ }^{\mathrm{b}}$ \\ ${ }^{a}$ Faculty of Business, Taylors University, 47500, Subang Jaya, Selangor, Darul Ehsan, Malaysia \\ ${ }^{\mathrm{b} B i n a}$ Pavo Family Business Institute, Persiaran Multimedia, Section 7, 40000 Shah Alam, Malaysia \\ *Corresponding author: shaistanoorsd@taylors.edu.my
}

Article history: Received:17 July 2019 Received in revised form: 08 April 2020 Accepted: 19 April 2020 Published online: 31 August 2020

\begin{abstract}
Education is considered as a driving force to accomplish the work efficiently. In this regard, business studies play an essential role in increasing the capabilities and skills of the individual as entrepreneurial orientation increase employment opportunities and act as a driving force to boost up the country's economy. Higher Education Institutions' role is significant in imparting entrepreneurial education among students, as Pakistani Higher Education Institutions have established the Entrepreneurship and Development Center (EDC), which is responsible for entrepreneurial training, seminar, workshops, discussion sessions, conferences, and entrepreneurial fairs. This paper aims to review the entrepreneurial education in developing Asia, specifically in Pakistan. This study is based on secondary data, taken from 30+ journal papers, 5+ HEC Annual Reports, and 4+ books in order to investigate the current trends of entrepreneurial education in developing countries, especially in Higher Education Institutions of Pakistan. The result shows that confronted challenges of entrepreneurial education in Pakistan are untrained staff in EDC, curriculum flaws, less governmental support, lack of subject experts and qualified faculty, and frequent changes in higher administration of universities. Recommendations have proposed for entrepreneurial success in Pakistani HEIs, and a model is proposed to follow.
\end{abstract}

Keywords: Entrepreneurship; universities; Pakistan; challenges; education

\begin{abstract}
Abstrak
Pendidikan dianggap sebagai daya penggerak untuk menyelesaikan tugas dengan berkesan. Dalam hal ini, kajian perniagaan memainkan peranan penting dalam meningkatkan keupayaan dan kemahiran individu, memandangkan orientasi keusahawanan meningkatkan peluang pekerjaan dan bertindak sebagai pemangkin untuk merancakkan ekonomi negara. Peranan Institusi Pendidikan Tinggi adalah penting dalam menyampaikan pendidikan keusahawanan di kalangan pelajar, memandangkan Institusi Pengajian Tinggi Pakistan telah menubuhkan Pusat Keusahawanan dan Pembangunan (EDC), yang bertanggungjawab untuk melaksanakan latihan keusahawanan, seminar, bengkel, sesi perbincangan, persidangan, dan pameran keusahawanan. Makalah ini bertujuan mengkaji semula pendidikan keusahawanan dalam membangunkan Asia, khususnya Pakistan. Kajian ini berdasarkan data sekunder, diperolehi dari 30 kertas jurnal, 5+ Laporan Tahunan HEC, dan 4+ buku untuk menyiasat tren semasa pendidikan keusahawanan di negara-negara membangun, terutamanya di Institusi Pengajian Tinggi di Pakistan. Hasil kajian menunjukkan bahawa cabaran yang didepani oleh pendidikan keusahawanan di Pakistan adalah kakitangan yang tidak terlatih di EDC, kekurangan kurikulum, kurang sokongan kerajaan, kekurangan pakar subjek dan fakulti yang berkelayakan, dan perubahan yang kerap berlaku di kalangan pentadbiran atasan universiti, Beberapa cadangan telah diajukan untuk kejayaan keusahawanan di IPT Pakistan, dan sebuah model juga turut disarankan untuk diikuti.
\end{abstract}

Kata kunci: keusahawanan; universiti; Pakistan; cabaran; pendidikan

(C) 2020 Penerbit UTM Press. All rights reserved

\subsection{INTRODUCTION}

Entrepreneurship is a terminology that has almost the same meaning in various languages. In the French language, entrepreneurship is derived from the word entreprendre means to undertake, whereas, in the Greek language, it means a set array of various terms like initiate, physical resources, and effort in an organised way to achieve objectives. Also, in the Italian translation of entrepreneurship is like intraprendere and untrenehmen in the German language. Hence, collectively all languages explain entrepreneurship in a framework of skills, capabilities, knowledge, and initiative (Schulte, 2004). Entrepreneurship comprises of a variety of skills and attitudes, starting from the capability to think in various directions, the courage to take a risk and putting the idea into practice (Gartner et al., 1995). Hence, entrepreneurship has played a pivotal role in business history, as it is treated as a separate academic field. Keeping in view the mid of nineteenth century, the economist has criticised the classical and neo-classical economic theories by identifying the ways of change of structure of economies. However, in the early twentieth century, various sociologists and historians moved away from the institutional perspective in order to highlight the role of entrepreneurs in the overall economic change cycle (Drysdale, 1996). Stobart (2000) stated that 
by mid -20th-century, researches done by economists and business historians revolves around the career of eighteenth-century entrepreneurs in order to understand the reasons behind the industrial revolution. Entrepreneurship plays a remarkable role in overall economic growth; therefore, entrepreneurial education may be considered as a key for economic development as education provides a vision to individuals for the evolution of ideas and help them to deal with societal problems (Alam, 2011; Nabi et al., 2008) and initiation of a new business venture. There are many ways to offer entrepreneurial education depending upon the desired objective if it is to increase the entrepreneurial understanding; in this regard, lectures, seminar, or media may play a prominent role (Refer to Figure 1). (Hytti et al., 2004; Batool et al., 2013). Similarly, if the objectives revolve around to prepare the individual with entrepreneurial skills, then industrial training may help in this regard whereas to inculcate the importance of entrepreneurship among student to be an entrepreneur, a practical methodology is the utilisation of controlled environment in order to facilitate the experiments via methodology of business simulation. (Hytti et al., 2004; Saeed et al., 2014).

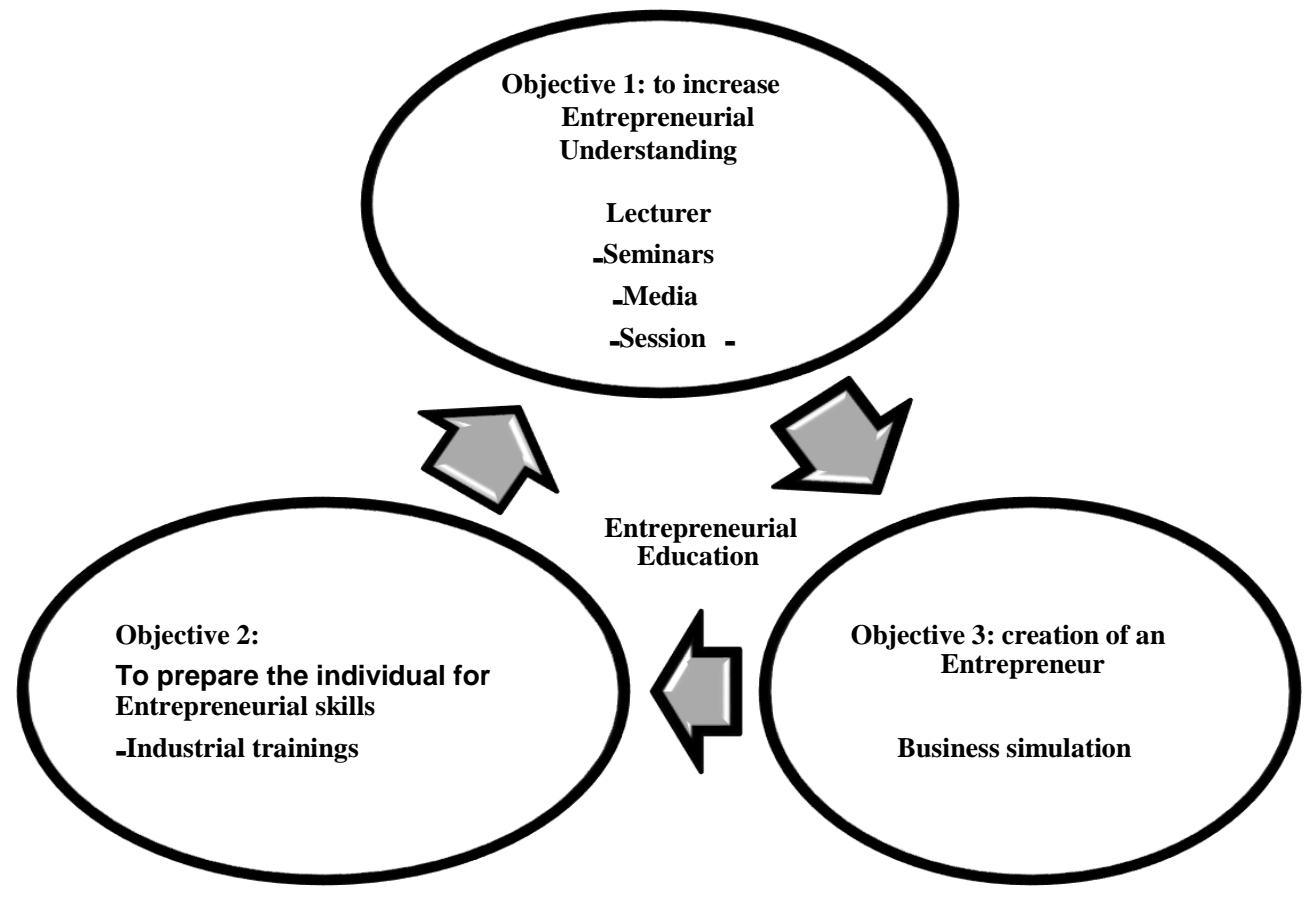

Figure 1 Methods to offer entrepreneurial Education Source: Authors adaptation from Literature

Hence, Entrepreneurship education provides the students with deep know-how about business regarding purpose, structure, and how the business interconnects with society as an economy. Thus, it helps to convey the skills that can be communicated through an educational system, which may benefit the individuals to develop an innovative plan (Klapper, 2004). Kourilsky et al., (1998) and Kroon et al., (2001) suggested that entrepreneurial education must start earlier in the education system precisely at the school level as it enhances the strength and skills among students to opt the business field after graduation seriously. Webb et al., (1982) stated that students usually initiate their business if they have participated in any entrepreneurial activity earlier. Past researches highlight that student who have taken entrepreneurship as a course among them $40 \%$ have established their business venture as Hederson et al., (2000) identifies that greater involvement of students has been seen in entrepreneurial activities which were introduced with entrepreneurship programs and participated in it (Carter et al., 1999; Galloway and Brown, 2002; Saeed et al., 2014; Noor et al. 2014).

Keeping in view the positive association between entrepreneurship education and entrepreneurship development, all across the globe, many countries have initiated to introduce entrepreneurial education in universities and colleges (Fayolle et al., 2006). In Pakistan, the Higher Education Commission (HEC), while recognising the importance of entrepreneurial education in the promotion of overall development and progress of the country, has taken an initiative of the development of Entrepreneurship and Development Center in Higher Education Institutions all across Pakistan. There are total of 135 Universities' in Pakistan comprising 74 (public) and 61 (private) and 1,993 colleges affiliated with Higher Education Commission Pakistan (SIU; HEC, 2012; HEC, 2013). However, universities are lacking in entrepreneurial staff and faculty; due to this reason, very few universities in Pakistan are offering entrepreneurship-related courses in their postgraduate and undergraduate program like the Institute of Business Administration (IBA), Lahore University of Management Sciences (LUMS) and Islamic College University. However, LUMS was the first educational institution, which has established the first center of Entrepreneurship in the year 1990, which is known as, Small and Medium Enterprise Center (ESMEC) in collaboration with Konrad-Adenauer Foundation, Germany (HEC, 2011).

Besides, the Institute of Business Administration (IBA), along with other public sector universities, are striving hard to establish the Centre of Entrepreneurship. Universities can play a role of nursery for the young entrepreneur. However, the quality of education plays a remarkable role in minimizing the gap between entrepreneur and business sectors (SIU; HEC, 2012). According to the National Business Accreditation Council (2016), 117 Business Schools are offering courses regarding the initiation and establishment of a business venture; still, the schools are not fulfilling the needs of students and the business sector. The current scenario of entrepreneurial education in 
Pakistan requires focused on Management Education as it moved towards building up an entrepreneurial culture for the creation of an entrepreneur. The universities in Pakistan lack in entrepreneurial education, and it should be added up as a separate specialisation under the umbrella of Management Education. Hence, the need of the hour is proper strategies to be adopted as entrepreneurial education will provide consistency and sustainability to the economic growth of Pakistan.

\subsection{LITERATURE REVIEW}

Entrepreneurial education is the growth and development of business knowledge, skills, and capabilities of individuals via related training programs. It accelerates the process of entrepreneurship by incorporating new business ventures and by making new regimes able to initiate a business (Ahmed et al., 2017) as it creates new employment opportunities resulting in the increased economic growth of the country. Thus, the entrepreneurial education is considered as a driving force, which accelerates the economic growth and vaccinates the business skills in individuals for the establishment of a business venture and making it valued (Brown, 2000; Muhammad et al., 2019). Moreover, it is considered as a program that focuses on the initiation and establishment of business under set defined rules and regulations as defined by the state (Audretsch, D. B. 2012;Batool, 2013). The entrepreneurial education plays an important role and fortified the students with the knowledge, skills that are required for the establishment of a new business venture along with motivating the individuals to set up their own business by enhancing their self-confidence (Khan, 2008; Haque, 2007; Kurato, 2005; Nabi et al., 2008; Muhammad et al., 2019). Researches highlight that all across the globe, educational development has occurred over the years in the field of entrepreneurship. The universities all around the world, specifically in developing countries are striving hard for the growth of entrepreneurial education by formulating and designing unique curricula of entrepreneurial education covering the latest trends in this field (Kruger et al., 2001; Kuratko et al., 2004; Tanveer et al., 2019). The estimate revealed that in the USA and European countries, remarkable work had been done in this field. As in the USA, entrepreneurial education has given almost 2,200 courses, at over 1,600 schools, 277 endowed positions, and 44 academic journals and the mainstream of management journals devoting more in the field of entrepreneurship (Muhammad et al., 2019). It is clear evidence that entrepreneurial education can be taught, and it proves the myth is false that entrepreneurs are born; actually, entrepreneurs are made (Nabi et al., 2008; Anjum et al., 2020). As stated by great management thinker of 20th century Peter Drucker (1985), the entrepreneurial mystique" is not magic, and it is not god gifted and no linkage with genes. Anyone can learn a discipline. Here, the role of Higher Education Institutions is considered as the facilitator to enhance the entrepreneurial culture and emphasis on entrepreneurial education as it will help to motivate the students from multi discipline for entrepreneurship (Shah et al., 2017). Universities impart the skills and teach the tactics to initiate a business venture among students; it also helps in the formulation of policies and infrastructure for entrepreneurship. Higher Education Institutions should stress on this strategy that a graduate is not only a job seeker, whereas, above all, a job creator (Schulte, 2004; Tanveer et al., 2020). According to the global competitive index report, Pakistan ranked at 129th position out of 144. Table 1 shows the Pakistan GCI ranking and global ranking that depicts the low GCI ranking from the year 2012-2017 as compared to the International GCI ranking (Refer to Figure 2).

Table 1 GCI's Pakistan ranking vs GCI's International Ranking

\begin{tabular}{|l|l|l|}
\hline Year & GCI's Pakistan ranking & $\begin{array}{l}\text { GCI's } \\
\text { Ranking } \\
\text { International }\end{array}$ \\
\hline $\mathbf{2 0 1 2 - 2 0 1 3}$ & 124 & 144 \\
\hline $\mathbf{2 0 1 3 - 2 0 1 4}$ & 133 & 148 \\
\hline $\mathbf{2 0 1 4 - 2 0 1 5}$ & 129 & 144 \\
\hline $\mathbf{2 0 1 5 - 2 0 1 6}$ & 129 & 140 \\
\hline $\mathbf{2 0 1 6 - 2 0 1 7}$ & 126 & 130 \\
\hline & Source: Global Competitiveness reports 2012-13, 2013-14, 2014-15, 2015-16, and 2016-17 \\
\hline
\end{tabular}


Global Competitive Index Pakistan Ranking Vs Global Competitive Index International Ranking

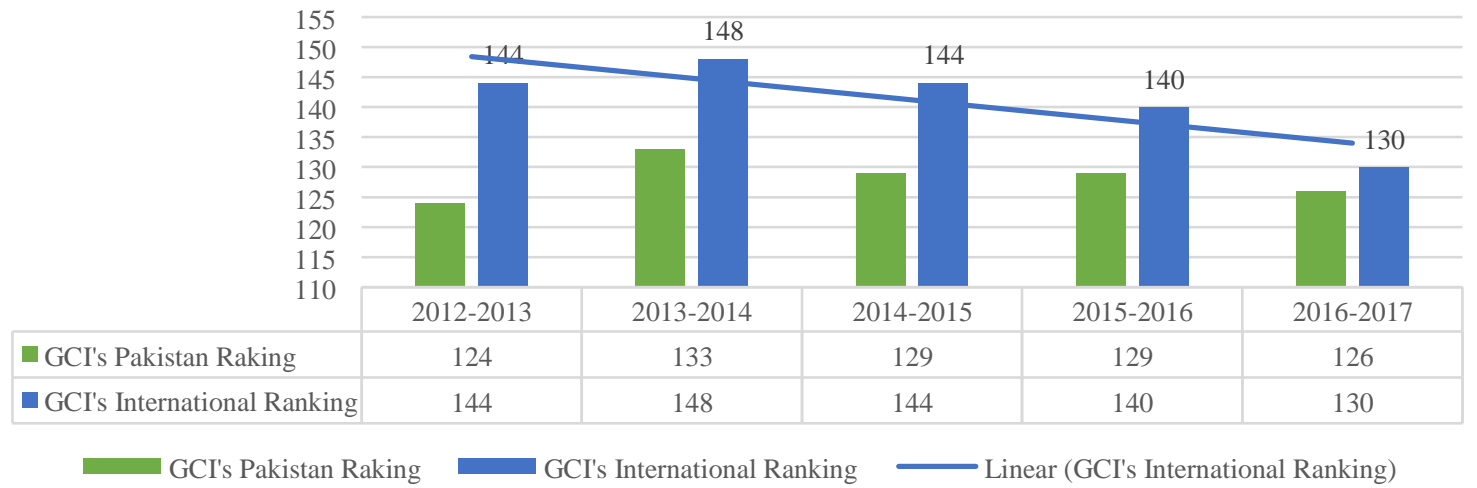

Figure 2 GCI's Pakistan ranking vs GCI's International Ranking

Haq (2007) stated that developing states could only be progress if they shift the knowledge base economies by stressing on plans concerning the technology, innovation, and particular focus on entrepreneurial education and entrepreneurship in order to create jobs. Subsequently, Alam (2011) stated that the attitude of people in Pakistan is quiet less promising towards entrepreneurial education and entrepreneurship as compared to other developing countries (Noor et al., 2014; Tanveer al., 2020 HEC, 2017). Higher Education Commission, Pakistan various projects concerning modernisation and capacity building, are in the pipeline. HEC's ongoing activities are concerned about strengthening the higher education system in the country. In this regard, various priority areas have been highlighted, and central importance is being given to setting a process regarding entrepreneurship education in Higher Education Institutions all across Pakistan. In this regard, HEC has announced policies for faculty development, incentive, and reward system also. Hence, faculty members all across Pakistani Higher Education Institutions are encouraged to research entrepreneurial education, as it is a topic of considerable debate (HEC 2016; Zareen et al., 2019).

Moreover, HEC, Pakistan is devoted to maintaining an entrepreneurial culture that boosts up the entrepreneurial education in universities of Pakistan. Still, the Higher Education Institutions lack behind in creating an entrepreneurial culture, entrepreneurial education, specific courses, and degree programs related to entrepreneurship. The present study will identify the significant challenges that occur as obstacles in the overall development of entrepreneurship education in Pakistani Higher Education Institutions. The study will be useful for policymakers to formulate the policies and procedures in order to promote entrepreneurial education in Higher Education Institutions of Pakistan.

\subsection{RESEARCH OBJECTIVE}

To identify the significant challenges in the development of entrepreneurship education in Pakistani HEIs.

\subsection{RESEARCH QUESTION}

What are the challenges that Pakistani HEIs are facing in the development of entrepreneurship education.

\subsection{METHODOLOGY}

This study is based on secondary data taken from various existing databases, publications, reports, and indexes in order to investigate the current trends of entrepreneurial education in developing countries, specifically in Pakistan. The secondary data is the evaluation of the data that has been collected by other researchers. The secondary data collection is economical easily accessible and provides a detailed background of a specific area of research (Andersen et al., 2011). Thus, the secondary data can be used for various purposes in order to solve a research problem or to give a better justification for a problematic issue (Boslaugh, 2007). However, there are some advantages of secondary data as compared to primary data collection. The secondary data comprises access to existing information, which is considered less time consuming as primary data, or it can be viewed as valid and authentic data as an experienced researcher has collected it. Thus, the data, which may primary at one time, maybe counted as secondary at another time. Hence, the difference between primary and secondary data is about the degree of detachment with the source. Subsequently, primary data usually used to be collected for fresh and for the very first time, whereas, secondary data constitute on already collected data. Therefore, once the primary data been used, they usually lost their original character and became secondary. However, secondary data may be published in the newspaper, periodicals, journals, and reports (Mcquarrie et al., 2011; Boslaugh, 2007). For the present study, 30+ journal articles, 5+ HEC Annual 
Reports, 5+ Entrepreneurship Books, and internal documents were utilised. Below, Table 2 mentioned the details regarding the material used for secondary data analysis.

Table 2 Details regarding type of Secondary Data collection

\begin{tabular}{|c|c|c|c|}
\hline Sr.no & Secondary Data Collection details & Quantity & Used in Analysis for \\
\hline 1 & $\begin{array}{l}\text { Journal Articles } \\
\text { (Ahmed, T., Chandran, V. and Klobas, J. (2017); Audretsch, D. B. } \\
\text { (2012); Alam, K (2011); Andersen, J. P., Prause, J., \& Silver, R. C. } \\
\text { (2011); Anjum, T., Ramzani, S. R., \& Nazar, N. (2020); Batool, I., } \\
\text { Xiaozhou, X., Shamsi, I. H., Hongshia, Z., Na, L., Weihui, M., \& } \\
\text { Hussain, S. S. (2013); Brown, C. (2000), Carter, S. and Collinson, E. } \\
\text { (1999), Drysdale, J. 1996; Fayolle, A. and Klandt, H. (2006); } \\
\text { Galloway, L. and Brown, W. (2002); Gartner, W. B. and Shane, S. } \\
\text { A. (1995): Gartner, W.B. and Vesper, K.H. (1994); Gorman, G. and } \\
\text { Hanlon, D. (1997); Haque, N. (2007); Henderson, R. and Robertson, } \\
\text { M. (2000); Hytti, U. and O’Gorman, C. (2004); Katz, J.A. (2003); } \\
\text { Khan, S. A. (2008); Klapper, R. (2004); Kourilsky, M. and Walstad, } \\
\text { W. (1998); Kroon, J. and Meyer, S. (2001); Krueger, B. A. \& } \\
\text { Lindahl, M. (2001); Kuratko, D. F. \& Hodgetts, R. M. (2004); } \\
\text { Kuratko, D.F. (2005); Mcquarrie E .F. (2011); Nabi, G. and Holden, } \\
\text { R. (2008); Noor, S., Ismail, K., Ali, S., \& Arif, A. (2014); Saeed, S. } \\
\text { and Muatto, M. and Yousafzai, S. (2014); Schulte, P. 2004; Shah, } \\
\text { N. and Soomro, B. (2017); Solomon, G.T., Weaver, K. M., \& } \\
\text { Fernald, L.W., Jr. (1994); Stobart, J. (2000); Tanveer, M., Haq, I. U., } \\
\text { \& Ali, H. (2020); Tanveer, Muhammad and Karim, Asif Mahbub } \\
\text { (2018; 2019); Zreen, A., Farrukh, M., Nazar, N., \& Khalid, R. } \\
\text { (2019). }\end{array}$ & $30+$ & $\begin{array}{l}\text { - } \quad \text { Discussion on } \\
\text { entrepreneurial } \\
\text { education in HEIs. } \\
\text { To identify the current } \\
\text { challenges and obstacles } \\
\text { in entrepreneurial } \\
\text { education in Pakistani } \\
\text { HEIs. } \\
\text { Best Practice Model for } \\
\text { Pakistani HEIs to be } \\
\text { followed }\end{array}$ \\
\hline 2 & $\begin{array}{l}\text { HEC Annual Report } \\
(2011,2012,2013,2015,2016,2017)\end{array}$ & $5+$ & \\
\hline 3 & $\begin{array}{l}\text { Books } \\
\text { Ajzen, I., \& Fishbein, M. (2014); Boslaugh, S. (2007); Drucker, P. } \\
\text { F. (1985); Muhammad Z.A; Paula.K, Fariha.G (2019); }\end{array}$ & $3+$ & \\
\hline
\end{tabular}

\subsection{FINDING AND ANYALYSIS}

\subsection{Obstacles In Field Of Entrepreneurial Education In Pakistani Higher Education Institutions}

Entrepreneurship has gain greater importance all across the world. The entrepreneurial education plays a vital role for overall development and progress of the country as more and more students to be an entrepreneur will increase the jobs and they will not only seek the job whereas but also create the jobs. In this regard, initiation and establishment of the business venture will ultimately boost the country's economy and overall development and progress of the country (HEC, 2008; Alam, 2011; Tanveer et al., 2019). Katz et al., (2003) stated that entrepreneurial education and maturity is a big question as the real maturity of entrepreneurship field is still to be experienced. Hence, young entrepreneurial faculty needs to be more skilled and trained in their particular area. Therefore, the need of the hour is teamwork to develop an entrepreneurial education curriculum and get it approved by higher authorities such as the academic council. Higher Education Institution lacks trained faculty in entrepreneurship as this field is in initial stages in developing countries like Pakistan. Hence, trained faculty should be hired in this particular area, specifically. In Pakistan, Higher Education Institutions may not able yet to establish the department of entrepreneurship as a separate discipline on undergraduate, postgraduate, and higher degrees in entrepreneurship due to lack of area experts in this field particularly. Thus, there is dire need to establish excellent Business Schools in Pakistan to initiate a Ph.D. program in Entrepreneurship as well as trained the current Higher Education Institutions faculty in this particular field. Therefore, the need of the hour is to hire more qualified faculty and experts in the field of entrepreneurship (Tanveer et al., 2020; Zareen et al., 2019). Furthermore, an expert from the industry sector can play a remarkable role in creating a strong university and industry linkage. Similarly, a faculty exchange program to best entrepreneurial universities all across the globe may groom the existing faculty members of Higher Education Institutions in Pakistan. HEC has taken the initiative in the development of Entrepreneurship and Development Centers in the universities 
of Pakistan. However, the hired staff members are not well qualified in the field of entrepreneurship; that is another reason for slow entrepreneurial activities in the education sector. Also, random change of Vice-Chancellors and Head of Department is another reason as in the period of one officer who works on progress and development on the entrepreneurship field used to be poorly affected due to different philosophies of academicians in one institution. It is badly needed to systematically deal with the progress of entrepreneurial education by joining hands with experts in this field (Noor et al., 2014; Muhammad et al., 2019; Tanveer et al., 2020).Moreover, Higher Education Institutions are in need to design an entrepreneurial education curriculum in detail. It is not a responsibility of a single individual, as it requires teamwork and dedication for the growth of entrepreneurship in Pakistani Higher Education Institutions (Zareen et al., 2019; Ahmed et al., 2017). Entrepreneurship education plays a remarkable role in strengthening the student capability to scan the opportunities in an economic, social, and cultural context. Thus, educational institutions have to play their role by inculcating the sense of collaboration, teamwork, creativity, and innovation among students. A student must be trained enough to see his limited resources and have the courage to work based on his powers and capability under his means and limits. Therefore, it is essential to realize the benefits associated with entrepreneurial education, as it has the potential to produce a student equipped with creativity, practical knowledge, innovation, inventiveness as these qualities will automatically contribute to the overall development and progress of the country. In order to achieve these objectives, practical learning must connect to educational learning as it also comprises of making a business plan, starts up, incubation centers, specifically in consultation with practicing entrepreneurs (Gartner et al., 1994; Katz, 2003; Khan, 2008; Tanveer et al., 2019 ). Entrepreneurship education requires a change in the existing curriculum as it is based on a practical and research-based approach rather than a typical classroom approach toward the marketing orientation of courses (Solomon et al., 2002; Mcquarrie et al., 2011; Ahmed et al., 2017). Figure 3 demonstrates the major obstacle in the field of Entrepreneurial Education in Pakistan.

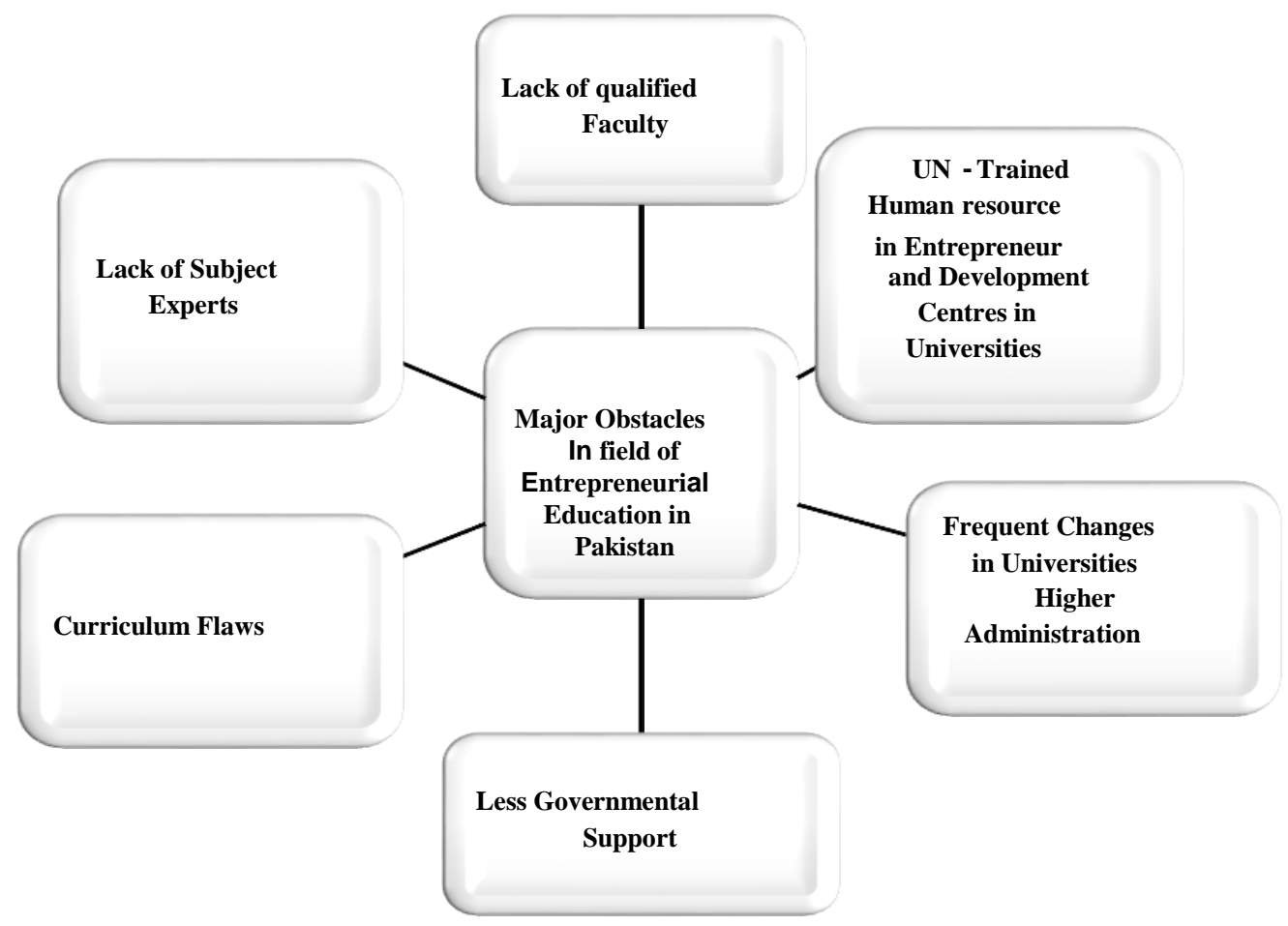

Figure 3 Major Obstacles in field of Entrepreneurial Education in Pakistan Source: Researcher adaption from Literature

\subsection{RECOMMENDATIONS}

Pakistan is a developing country, and it requires a vibrant approach to entrepreneurial education, which is very important for societal development and progress. Thus, success comes to those who involve concerned stakeholders in particular tasks. Therefore, the public and private sectors need to be involved in research and information dissemination. The following are the proposed recommendation for the success of entrepreneurial education in Pakistani HEIs.

1. Pakistan needs enhancing research activities, especially in the field of entrepreneurship education. It will bring enhanced knowledge on the subject area and help to identify the weaknesses and increase the body of Literature. It will play an essential role in the development and application of entrepreneurial practices. 
2. Universities may play a dynamic role by conducting awareness sessions via the involvement of students in order to inculcate the value of entrepreneurial education among the young generation. Similarly, faculty members may interact with expert personnel to have a discussion session on the campus for raising awareness and developing command on this subject area.

3. Universities should collaborate with international universities in various projects, exchange experiences with other countries will help to see entrepreneurial education to be viewed as an international perspective.

4. There is a dire need for training of the existing faculty members, whereas pre-service training and in-service training both are necessary in order to achieve a grip on this subject as teaching staff needs command on the subject of entrepreneurship.

5. A collaborative project with local enterprises and other players in the community will enhance the knowledge regarding entrepreneurial education, and it will increase the motivation for collaborative projects to enhance entrepreneurial activities.

6. Successful implementation of entrepreneurial education requires long-term thinking, constant support, and coordination from the Higher Education Commission, Pakistan. Furthermore, variation in modules may introduce under the umbrella of entrepreneurship like Creative Industry Management, Entrepreneurship and Area Development, Entrepreneurship and Innovation, Business and Entrepreneurship, etc. Based on the best practices depicted in Figure 4, a model is proposed (refer to Figure 4) to highlight the major obstacle in the field of entrepreneurial education success. The model demonstrates the responsibilities on the part of Universities and government. Such as faculty training, curriculum revisions, and collaborative projects with local governments, the introduction of entrepreneurship subjects at the school level, degree program in entrepreneurship, EDC staff entrepreneurial training, faculty exchange program are considered as the essential steps, which Pakistani Higher Education Institutions must follow to accelerate entrepreneurial education.

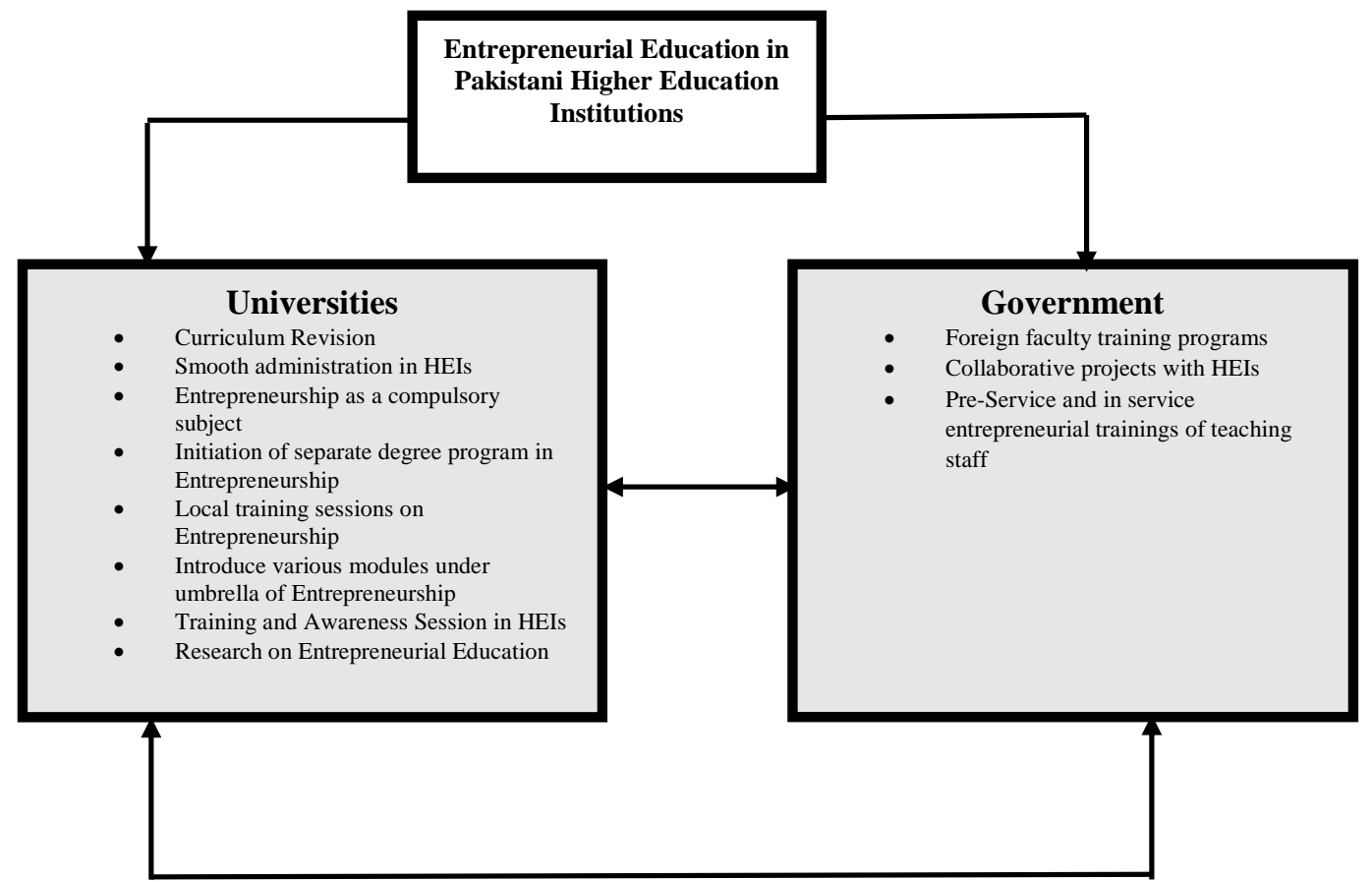

Figure 4: Proposed Model for Pakistani Higher Education Institutions (Source: Researcher adaption from Literature)

\subsection{THEORETICAL JUSTIFICATION}

\subsection{Sustainability Entrepreneurship Theory}

Higher Education Institutions are the pillars of imparting knowledge to society, and they must focus on divulging the entrepreneurial education as various industrialized countries are facing the challenge of unemployment (Filzah et at., 2016). Thus, creating the entrepreneurial mindset will come up with job creators rather than job seekers. Hence, sustainability is treated as custodians for the social challenge of employability (Kirzner 1985; Venkataraman, 1997). Researchers argued about the strong connection between behavior, management, and sustainability. That is why HEIs must provide opportunities to carve the entrepreneurial mindset of students by providing them quality entrepreneurship education (Aragon et al., 2003; Lenox, 2006). Thus, the entrepreneurship viewpoint in HEIs will show how entrepreneurial opportunities may come up with sustainability and fruitful results, especially for the overall development and progress of the country (Marcati et al., 2008). Hence, entrepreneurial education in HEIs may be considered as a tool for the overall development and progress of the country. 


\subsection{CONCLUSION}

Entrepreneurship has gained an essential place in the contemporary education system. It is imperative to introduce and apply entrepreneurial education in the existing education system. Entrepreneurship should add up as a new discipline in the education system like other fields. The industrial and technological advancement demand revision in the education system in particular. There is a dire need to introduce new modules concerning the entrepreneurial education in universities of Pakistan. The universities are building a block of the economy. Therefore, the primary responsibility comes on the shoulder of universities from initiation until the establishment of entrepreneurial education. The proposed model (refer to Figure 4) need to follow to accelerate the process of entrepreneurial education in Pakistan. It would help to develop an entrepreneurial society that will increase the individual entrepreneur's and will bring job opportunities and cut down the problem of unemployment and will play a dynamic role in the development and progress of the country.

\section{References}

Ahmed, T., Chandran, V. and Klobas, J. (2017), "Specialized entrepreneurship education: does it really matter? Fresh evidence from Pakistan", International Journal of Entrepreneurial Behavior \& Research, 23(1), 4-19. https://doi.org/10.1108/IJEBR-01-2016-0005

Ajzen, I., \& Fishbein, M. (2014). Understanding attitudes and predicting social behavior. NJ: Prentice Hall.

Alam, K. (2011). Global Entrepreneurship Monitor: Pakistanis less enthusiastic about entrepreneurship. Retrieved from http://tribune.com.pk/http://tribune.com.pk/story/311603/global-entrepreneurship-monitor-pakistanislessenthusiastic-about-entrepreneurship/. Access date: 24 December 2011

Andersen, J. P., Prause, J., \& Silver, R. C. (2011).A Step-by-Step Guide to Using Secondary Data for Psychological Research. Social and Personality Psychology Compass, 5(1), 56-75.

Anjum, T., Ramzani, S. R., \& Nazar, N. (2020). Antecedents of Entrepreneurial Intentions : A Study of Business Students from Universities of Pakistan, 1(2), 72-88.

Aragon-Correa, J.A., Sharma, S., 2003. A contingent resource-based view of proactive corporate environmental strategy. Academy of Management Review, 28(1), 7188.

Audretsch, D. B. (2012). Entrepreneurship: A Survey of the Literature: Report Prepared for the European Commission, Enterprise Directorate General.

Batool, I., Xiaozhou, X., Shamsi, I. H., Hongshia, Z., Na, L., Weihui, M., \& Hussain, S. S. (2013). A Brief Overview of Current Situation and Perspective of Entrepreneurship Education in Pakistan with Respect to other Countries, 15-20.

Boslaugh, S. (2007). Secondary data sources for public health: A practical guide. New York, NY: Cambridge.

Brown, C. (2000), Entrepreneurial Education Teaching Guide, 00-7, CELCEE Kaufman Centre for Entrepreneurial Leadership Clearinghouse on Entrepreneurship Education, available at:www.celcee.edu/publications/digest/Dig00-7,html/vol.00-7. Access date: 12 June 2012

Carter, S., \& Collinson, E. (1999). Entrepreneurship education: Alumni perceptions of the role of higher education institutions. Journal of Small Business and Enterprise Development, 6(3), 229-239. doi:10.1108/eum0000000006679

Drucker, P. F. 1985. Innovation and Entrepreneurship: Practice And Principles. Harper and Row: New York.

Drysdale, J. 1996. How are social-scientific concepts formed? A Reconstruction Of Max Weber's Theory Of Concept Formation. Sociological Theory. 14(1), 71-88.

Fayolle, A. and Klandt, H. (2006), "Issues and newness in the field of entrepreneurship education: new lenses for new practical and academic questions", in Fayolle, A. and Klandt, H. (Eds), International Entrepreneurship Education Issues and Newsness, Edward Elgar, Northampton, MA, 1-20.

Filzah, I., Norezam, S.O. and Maheran, N.N.M. (2016) 'Postgraduate students recruitment strategies in higher education institutions of Malaysia', International Review of Management and Marketing, 6(8), 166-174.

Galloway, L. and Brown, W. (2002), "Entrepreneurship education at university: a driver in the creation of high growth firms?" Education p Training, 44(8/9), 398-405.

Gartner, W. B. and Shane, S. A. 1995. Measuring entrepreneurship over time. Journal of Business Venturing. 10(4), 283-301.

Gartner, W.B. and Vesper, K.H. 1994. Executive forum: experiments in entrepreneurship education: successes and failures. Journal of Business Venturing, 9, 179-187.

Gorman, G. and Hanlon, D. (1997), "Some research perspectives on entrepreneurship education, enterprise education and education for small business management: a ten-year literature review", International Small Business Journal, 15, 56-78.

HEC (2012).Medium Term Development Framework II, MTDF - HE II, Higher Education Commission, Pakistan.

HEC (2013). Task Force on Improvement of Higher Education in Pakistan. Annual Report, Higher Education Commission, Pakistan.

Higher, P., \& Briefed, M (2017) HEC Learning Innovation, 2016, Pakistan (www.hec.gov.pk). HEC (2017). Task Force on Improvement of Higher Education in Pakistan. Annual Report, Higher Education Commission Pakistan.

HEC (2011-2015).Medium Term Development Framework II, MTDF - HE II, Higher Education Commission Pakistan.

HEC (2012).Medium Term Development Framework II, MTDF - HE II, Higher Education Commission, Pakistan.

HEC Learning Innovation, 2012, Pakistan. HEC Statistical Information Unit, Pakistan (2008-2012).

HEC (2013). Task Force on Improvement of Higher Education in Pakistan. Annual Report, Higher Education Commission, Pakistan.

Higher Education Commission (2016). Annual Report 2015-2016. https://www.hec.gov.pk/english/news/HECPublications/Annual\%20Report\%202015-16.pdf.

Henderson, R. and Robertson, M. (2000), "Who wants to be an entrepreneur? Young adult attitudes to entrepreneurship as a career", Career Development International, 5(6), 27987.

Higher Education Commission, Pakistan and Statistics on higher education in Pakistan. [Online] Accessed on $20^{\text {th }}$ May 2008 from: http://www.hec.gov.pk/QualityAssurance/Statistics.html.

Hytti, U. and O'Gorman, C. (2004), "What is enterprise education? An analysis of the objectives and methods of enterprise education programmes in four European countries", Education Training, 46(1), 11-23.

Katz, J.A. (2003), "The chronology and intellectual trajectory of American entrepreneurship education”, Journal of Business Venturing, 18(2), 283-300.

Khan, S. A. (2008). Significance of Entrepreneurial Education in Higher Education. Paper presented at the 8th International Entrepreneurship Forum (IEF), International Conference on Creativity and Entrepreneurship, Ahmadabad, India.

Klapper, R. (2004), "Government goals and entrepreneurship education: an investigation at a Grand Ecole in France", Education Training, 46(3), 127-37.

Kourilsky, M. and Walstad, W. (1998), "Entrepreneurship and female youth: knowledge, attitudes, gender differences, and educational practices", Journal of Business Venturing, 11(1), 77-89.

Kirzner, I.M., 1985. Discovery and the Capitalist Process. University of Chicago Press, Chicago, IL.

Kroon, J. and Meyer, S. (2001), "The role of entrepreneurship education in career expectations of students", South African Journal of Higher Education, 15(1), 47-53.

Krueger, B. A. \& Lindahl, M. (2001). Education for Growth: Why and for Whom? Journal of Economic Literature, 39, 1101-1136.

Kuratko, D. F. \& Hodgetts, R. M. (2004). Entrepreneurship: Theory, Process, Practice. Mason, Ohio: South-Western College Publishers.

Kuratko, D.F. (2005). The Emergence of Entrepreneurship Education: Development, Trends and Challenges. Entrepreneurship Theory and Practice, 29(5), 577-598.

Lenox, M., 2006. The role of private, decentralized institutions in sustaining industry self-regulation. Organization Science 17 (6), 670-690.

Marcati, A., Guido, G., Peluso, A.M., 2008. The Role Of SME Entrepreneurs' Innovativeness And Personality In The Adoption Of Innovations. Research Policy 37(9), $1579-1590$ 
Mcquarrie E.F. (2011). The Market Research Toolbox: A Concise Guide for Beginners, 3rd Edition. Thousand Oaks, CA: Sage Publications, Inc.

Muhammad Z.A; Paula.K, Fariha.G (2019) The Role and Impact of Entrepreneurship Education DOI: https://doi.org/10.4337/9781786438232.00013.

Nadeem U1 Haque (2007). "Entrepreneurship in Pakistan," PIDE-Working Papers 2007:29, Pakistan Institute of Development Economics?

Nabi, G. and Holden, R. (2008), "Graduate entrepreneurship: intentions, education and training", Education and Training, 50(7), 545-55. O "rebro.

Noor, S., Ismail, K., Ali, S., \& Arif, A. (2014). Knowledge creating capabilities and academic entrepreneurship. World Applied Sciences Journal, 32(7). https://doi.org/10.5829/idosi.wasj.2014.32.07.964.

National Board of Accreditation (NBA). (2016). NBAs accreditation parameters criteria and processes. Retrieved 12 November 2016 from http://www.nbaind.org/En/1051-nbas-accreditation-parameters-criteria-and-processes.aspx

Saeed, S. and Muatto, M. and Yousafzai, S. (2014) 'A multi-level study of entrepreneurship education among Pakistani university students.' Entrepreneurship Research Journal. 4 (3), 297-321.

Schulte, P. 2004. The entrepreneurial university: a strategy for institutional development. Higher Education in Europe. 29(2), 187-191.

Shah, N. and Soomro, B. (2017), "Investigating entrepreneurial intention among public sector university students of Pakistan", Education + Training, 59(7/8), 841855. https://doi.org/10.1108/ET-11-2016-0168.

Solomon, G.T., Weaver, K. M., \& Fernald, L.W., Jr. (1994). Pedagogical Methods of Teaching Entrepreneurship: A Historical Perspective. Simulation and Gaming, 25(3), 338-353.

Stobart, J. 2000. In search of causality: a regional approach to urban growth in eighteenth-century England. Human Geography. 82(3), 149-163.

Tanveer, M., Haq, I. U., \& Ali, H. (2020). Academic policy and entrepreneurship : Pakistan Perspective DigitalCommons @ University of Nebraska - Lincoln Academic policy and entrepreneurship : Pakistan Perspective, (January).

Tanveer, Muhammad and Karim, Asif Mahbub Dr., "The Use of Performance Measurement in Universities of Pakistan". Library Philosophy and Practice (e-journal). 3010. https://digitalcommons.unl.edu/libphilprac/3010. Sep. 2019

Venkataraman, S.,1997. The distinctive domain of entrepreneurship research: an editors' perspective. In: Katz, J., Brockhaus, J. (Eds.), Advances in Entrepreneurship, Firm Emergence, and Growth, 141-160.Springer, New York, NY

Webb, T., Quince, T. and Wathers, D. (1982), Small Business Research: The Development of Entrepreneurs, Gower, Aldershot.

Zreen, A., Farrukh, M., Nazar, N., \& Khalid, R. (2019). The Role of Internship and Business Incubation Programs in Forming Entrepreneurial Intentions: an Empirical Analysis from Pakistan. Journal of Management and Business Administration. Central Europe, 27(2), 97- 113. 